\title{
MATHEMATICAL MODELING AND NUMERICAL SOLUTION OF IRON CORROSION PROBLEM BASED ON CONDENSATION CHEMICAL PROPERTIES
}

\author{
BASUKI W. ${ }^{1}$, ARIF F. ${ }^{2}$ AND Tri R. ${ }^{2}$ \\ ${ }^{I}$ Department of Mathematics, Institut Teknologi Sepuluh Nopember,Surabaya, Indonesia. \\ ${ }^{2}$ Department of Mathematics \& Industrial Technology, Jamber University-Wijaya Kusuma \\ Surabaya University, Jamber-Surabaya, Indonesia. \\ b_widodo@matematika.its.ac.id
}

\begin{abstract}
Corrosion process is a natural phenomenin that occurs with the various metals, where the corrosion process in electrochemical environment can be explained by using a galvanic cell. The iron corrosion process is based on the acidity degree $(\mathrm{pH})$ of a condensation, iron concentration and condensation temperature of electrolyte. These are applied at electrochemistry cell. The iron corrosion process at this electrochemical cell also is able to generate electrical potential and electric current during the process. This paper considers how to build a mathematical model of iron corrosion based on electrical potential and electric current. The mathematical model further is solved using the finite element method. The iron corrosion model is built based on the iron concentration, condensation temperature, and iteration time applied. In the electric current density model, the current is generated between the cathode and anode poles and the iteration time applied. Whereas the potential electric model, is based on the electric potential and the iteration time applied. The numerical results show that the part of iron sample, attacked by corrosion, is a function of time, depth difference, iron concentration, condensation temperature and the sum of reduced mass during corrosion process.
\end{abstract}

ABSTRAK: Proses kakisan adalah kes semulajadi yang berlaku di pelbagai logam, di mana proses kakisan dalam elektrokimia boleh diterangkan dengan menggunakan sel galvani. Proses pengaratan besi adalah berdasarkan kepada tahap keasidan $(\mathrm{pH})$ daripada pemeluapan, kepekatan besi dan suhu pemeluapan elektrolit. Sifat-sifat ini digunakan pada sel elektrokimia. Proses pengaratan besi pada sel elektrokimia ini juga mampu menjana arus dan voltan elektrik. Kertas ini menerangkan cara-cara membina model matematik untuk kakisan besi, arus dan voltan elektrik. Model matematik ini diselesaikan dengan menggunakan kaedah unsur terhingga. Model kakisan besi dibina berdasarkan kadar kepekatan besi, suhu pemeluapan, dan lelaran. Ketumpatan arus elektrik berdasarkan jumlah arus elektrik yang ada tiang-tiang katod dan anod tiang pada setiap lelaran. Manakala model potensi elektrik, berdasarkan pada kadar awal voltan elektrik pada masa lelaran. Bacaan experimen menunjukkan bahawa bahagian anod tetap keras walaupun dikakis dan dipengaruhi oleh kepekatan besi dan suhu pemeluwapan dan jumlah jisim.

KEYWORDS: iron corrosion; concentration of iron; electrochemical cell; finite element method. 
Basuki et al.

\section{INTRODUCTION}

Iron is one of the most important metals that has many benefits to the human society. Corrosion of iron happened naturally. Rustiness can be described as a material ruination by action which embossing area, where resistance of a material on the rustiness depends on the numerous variables such as material properties and environmental characteristics [1].

The important aspect in a material rustiness is mass transport characteristic, that occur due to evacuation of temperature, migration and diffusion. The distribution character from the effects which are generated in an object depends on force system characteristic and itself object.

A real rustiness case is a galvanic process with metal that works as an anode, a cathode and as one conductor for the electrons. The quantitative simulation of iron rustiness relates to possibility that deterioration forecasting of conglomerate stones are contain the iron item, thus here pointed to build a rustiness model as possible as free of context in physically and can be interfaced to a model of chemical reaction. This paper focuses on a mathematical modeling of an electro chemistries reaction that taken place during corrosion process and the model then solved using finite element method, in which it is shown geometrically as an electrochemistry cell process. This paper illustrates the reduction-oxidation reaction in electrochemistry cell by using a partial differential model based on the law of physical chemistry.

\section{GOVERNING EQUATION}

The important aspect in a material rustiness is mass transport characteristics, which are occurred because of temperature, migration and diffusion evacuation. These are appropriate with condensation mass $J_{k}$ of species $k$, as mentioned in Planck-Nernst's law, i.e.:

$$
J_{k}=-D_{k} \underline{\nabla} C_{k}-C_{k} \underline{\nabla \emptyset}
$$

where :

$D_{k}=$ diffusion constant

$C_{k}=$ concentration in Molar (moles/liter)

$z_{k}=$ charge number

$F=$ Faraday's constant

$\emptyset=$ the electric potential in the electrolyte

$R=$ gas constant

$T=$ absolute temperature

This condensation mass further is transported by electrical field on molecular diffusion process [2]. For each type, the equation of transportation can be written in a form of accumulator acid, i.e.:

$$
\frac{a C_{k}}{a t}+\nabla \cdot\left[\left(-\frac{z_{k} F D_{k}}{R T} \nabla \emptyset\right) \cdot C_{k}\right]-D_{k} \nabla^{2} C_{k}=S_{k}
$$


where $S_{k}$ is ions production or ruination of type $k$, for example in elimination case from $\mathrm{Fe}^{+2}$ ion because of rust forming. In this corrosion process case, it is taken place in the interface between electrodes and condensation of electrolyte.

Electrical tension can be obtained by considering the total electrical current and it disregards the neutrality electric condensation of electrolyte. Newman (1996) explains that the power of the electrical current $I$, in condensation of the electrolyte, is flown in the condensation mass constant change from iron. It can be formulated using the Faraday's law:

$$
i=F \sum_{k} z_{k} J_{k}
$$

A statement of electro-neutrality is that the electric current density is non-divergent, that is:

$$
\nabla . \mathrm{i}=0
$$

Inserting the Expression (3) in Equation (4), we obtain:

$$
\nabla \cdot\left(\Sigma_{k} z_{k} J k\right)=0
$$

By using the Planck-Nernst's law (1), we then end up with an equation for the electric potential, i.e.:

$$
\nabla\left[\left(\sum_{k} \frac{\Xi_{k} F D_{k}}{R T} C k\right) \nabla \emptyset\right]=-\sum D_{k} \nabla^{2} C_{k}
$$

Notice that when the concentration gradients may be neglected, Eq. (6) then reduces to the Laplace's equation, i.e.:

$$
\nabla^{2} \emptyset=0
$$

\section{BOUNDARY CONDITIONS}

By analyzing the electrochemistry, iron rustiness process is event of iron metal oxidation by the oxygen that comes from the air. Figure 1 shows that $\mathrm{H}_{2} \mathrm{O}$ condensation electrolyses with $(\mathrm{Fe})$ iron electrode. In this condensation there are some species, for example $\mathrm{H}^{+}$and $\mathrm{OH}^{-}$ions obtained from the result of $\mathrm{H}_{2} \mathrm{O}$ ionization as solvent and $\mathrm{Fe}^{2+}$ ion that come from electrode ionization. $\mathrm{Fe}^{2+}$ ions peripatetic towards negative pole and $\mathrm{OH}^{-}$ions peripatetic towards positive pole [4]. 

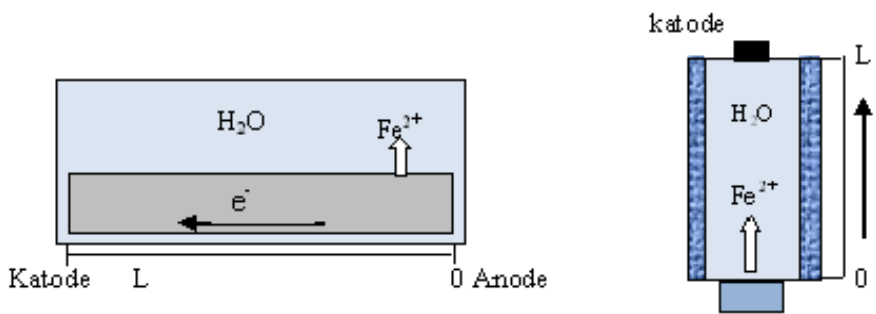

Fig. 1: (a) Location of the anode and cathode in a corrosion process (b) and a onedimensional galvanic cell.

During the corrosion process takes place, it will entangle the reaction of reductionoxidation (redox) in electrolytic cell by using a partial differential model, based on law of physical chemistry. Newman (1996) explains that the only reaction takes place in anode is disconnection of metal. In this case, reaction of $(\mathrm{Fe})$ iron can be written as:

$$
(\mathrm{A}) \mathrm{Fe} \rightarrow \mathrm{Fe}^{2+}+2 \mathrm{e}-, \mathrm{E}_{\mathrm{A}}^{0}=-0,44 \text { (oxidation) }
$$

where $\mathrm{E}_{\mathrm{A}}^{0}$ is the standard potential of (A) reaction. The current density is produced by (A) reaction and it can be written by the Butler-Volmer's equation as:

$$
i_{A}=i_{O A} .\left\{\exp \left[\left(1-\alpha_{A}\right) \frac{F_{I A}}{h T} \eta_{A}\right]-\exp \left[-\alpha_{A} \frac{F_{I A}}{\pi T} \eta_{A}\right]\right\}
$$

where :

$i_{O A}=$ exchange current density of (A) reaction, that is the current density evaluated, in which the net current at the electrode is null (this value is obtained experimentally),

$\dot{\alpha}_{A}=$ transfer coefficient for (A) reaction (this value is obtained experimentally, although a good estimate is $1 / 2$ ),

$z_{A}=$ number of electrons participating in (A) reaction,

$\dot{\eta}_{A}=$ overvoltage $=$ äö $-\mathrm{E}_{\mathrm{A}}$, where äö is the variation in potential between the electrode and the electrolyte (soon after the electronic double layer) and $\mathrm{E}_{\mathrm{A}}$ is the electrode potential at zero current.

As only the species $\mathrm{Fe}^{2+}$ are involved in the anode reaction, we can assume that its mass flux will be non-zero only. Hence, once the density current is evaluated from Eq. (2), we can use the Faraday's law to evaluate the mass flux:

$$
\begin{array}{r}
\mathrm{J}_{\mathrm{fe} 2}{ }^{+}=\frac{i_{A}}{F z_{F s}+z} \\
\mathrm{~J}_{\mathrm{H}+}=0 \quad ; \text { on } \mathrm{x}=0 .
\end{array}
$$

The fluxes are then used as boundary condition at the anode for the transport equation.

Further, the cathode pole, between the easiest matters experiences reduction is $\mathrm{H}_{2} \mathrm{O}$ molecule so that happened reduction to $\mathrm{H}_{2} \mathrm{O}$ : 


$$
\text { (B) } 4 \mathrm{H}^{+}+\mathrm{O}^{2}+4 \mathrm{e}^{-} \rightarrow 2 \mathrm{H}_{2} \mathrm{O} ; \mathrm{E}_{\mathrm{B}}^{0}=1,23 \mathrm{~V} \text {. }
$$

The cathodes current density can once again be evaluated according to the ButlerVolmer's equation, by considering the (B) reaction only:

$$
i_{B}=-i_{O B}\left\{\operatorname{sxp}\left[\left(1-\alpha_{D}\right) \frac{F_{B D}}{R T} \eta_{E}\right]-\exp \left[-\alpha_{B} \frac{F_{B Z}}{R T} \eta_{E}\right]\right\},
$$

where :

$i_{O B}=$ exchange current density of (B) reaction,

$\dot{\alpha}_{B}=$ transfer coefficient for (B) reaction,

$z_{B}=$ number of electrons participating in (B) reaction,

$\dot{\eta}_{B}=$ over voltage,

with the negative sign it means that the flow of current proceeds from the electrode to the electrolyte, on the reverse of direction with respect to the axis.

The boundary conditions for the Transport Equations (2) are obtained as before, by considering that only the $\mathrm{H}+$ species are involved in the cathode reaction, and therefore only its mass flux will be non-zero:

$$
\left.\begin{array}{c}
J_{F e 2+}=0 \\
J_{H}^{+}=\frac{i_{B}}{F z_{H^{+}}} \quad ; \text { on } x=L
\end{array}\right\}
$$

\section{INITIAL CONDITIONS}

Every condensation has degree of acidity (hydrogen ion exponent) different and influences to the corrosion process of a metal. Svante Arhenius comments that acid is a compound, which if it is dissolved in water then it will yield $\left(\mathrm{H}^{+}\right)$Hidronium ion. While alkaline is a compound dissolved in water will yield $\left(\mathrm{OH}^{-}\right)$Hydroxide ion [4]. As known, a small fraction from $\left(\mathrm{H}_{2} \mathrm{O}\right)$ water molecules are dissociated in $\mathrm{H}^{+}$and $\mathrm{OH}^{-}$ions in the amount are determined by the constant equilibrium from dissociation reaction, that is:

$$
\mathrm{H}_{2} \mathrm{O} \quad \mathrm{H}^{+}+\mathrm{OH} \rightleftarrows
$$

Concentration of $\left(\mathrm{H}^{+}\right)$Hydronium ion and $\left(\mathrm{OH}^{-}\right)$Hydroxide ion in a liquid condensation generally very low but hardly determines characters of condensation, especially condensation in water. Sorensen (1868-1939) further proposes $\mathrm{pH}$ and $\mathrm{pOH}$ concept to avoid usage of a real small number [4]. According to Sorensen $\mathrm{pH}$ and $\mathrm{pOH}$ are the function of negative logarithm from the concentration of $\mathrm{H}^{+}$and $\mathrm{OH}^{-}$ions in a condensation, and formulated as follows:

$$
\mathrm{pH}=-\log \left[{C_{H}}^{+}\right] \text {dan } \mathrm{pOH}=-\log \left[\mathrm{C}_{\mathrm{OH}^{-}}\right]
$$

with $\mathrm{C}_{\mathrm{H}}{ }^{+}$is concentration from ion $\mathrm{H}^{+}$and $\mathrm{COH}_{\mathrm{OH}}{ }^{-}$is concentration of $\mathrm{OH}^{-}$ion where at equilibrium of pure water, applies: 


$$
\mathrm{pH}+\mathrm{pOH}=14
$$

Those concentration of the ions expressed in a set of Molar (M), where the molarity expresses that the various solute moles in every 1 condensation liter ( mol/liter). Pure water has $\mathrm{pH}=7$, so that concentration from both of good ions of $\mathrm{H}^{+}$and $\mathrm{OH}^{-}$ions equal to $10^{-7}$ Molar. Smaller $\mathrm{pH}$ value of condensation hence level of the solution acidity excelsior and so do on the contrary.

\section{RESULTS AND DISCUSSION}

Finite element method is one of approach method of numeric that bases on the problems at every part of element that is named by finite element. Every problem that exists will be finalized with the quadratic approach, where the problem solving form finite element method has form of matrix equation:

$$
[K]\{r\}+\left[K_{t}\right]\{r\}=\{R\}
$$

where:

$[K],\left[K_{t}\right]=$ assemble matrix

$\{r\}=$ vector from node magnitude which unknown

$[R]=$ assemble style parameter vector

Global matrix equation hereinafter will be finalized to time, where in this solution it will be used approach of finite difference with the Crack-Nicholson's pattern. Equation of global matrix compiler can be written down in the form of finite difference as:

$$
\begin{array}{r}
{[K]\left(\theta[r\}_{t+\Delta t}+(1-\theta)\{r\}_{t}\right)+} \\
{\left[K_{t}\right]\left\{\theta\left\{\frac{\partial\{r\}}{\partial t}\right\}_{t+\Delta t}+(1-\theta)\left\{\frac{\partial\{r\}}{\partial t}\right\}_{t}\right\}=\{R\}_{t+\Delta t}}
\end{array}
$$

If it is taken è $=1 / 2$ hence will be obtained Crack-Nicholson's pattern, with approach pattern:

$$
\left.\frac{1}{2}\left\{\left\{\frac{\partial[r]}{\partial t}\right\}_{t+\Delta t}+\left\{\frac{\partial[r]}{\partial t}\right\}\right\}_{t}\right\} \cong \frac{\{r\}_{t+\Delta t}-\{r\}_{t}}{\Delta t}
$$

Global matrix equation therefore will have a form of approach to time as follows:

$$
\left([K]+\frac{2}{\Delta t}\left[K_{t}\right]\right)\{r\}_{t+\Delta t}=2\{R\}_{t+\Delta t}-\left([K]-\frac{2}{\Delta t}\left[K_{t}\right]\right)\{r\}_{t}
$$


IIUM Engineering Journal, Vol. 12, No. 6, 2011: Special Issue in Science and Ethics

Basuki et al.

The numerical solution of those equations which will be visualized by using MATLAB 7.0 program. The result is shown in Fig. 2:

(a)

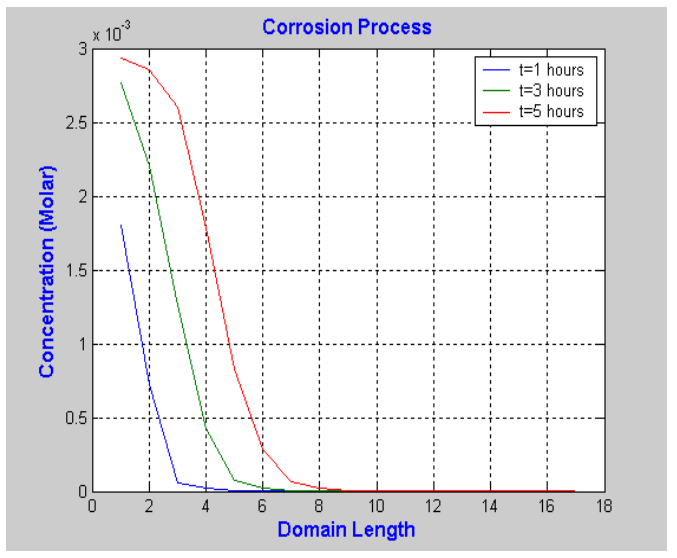

(b)

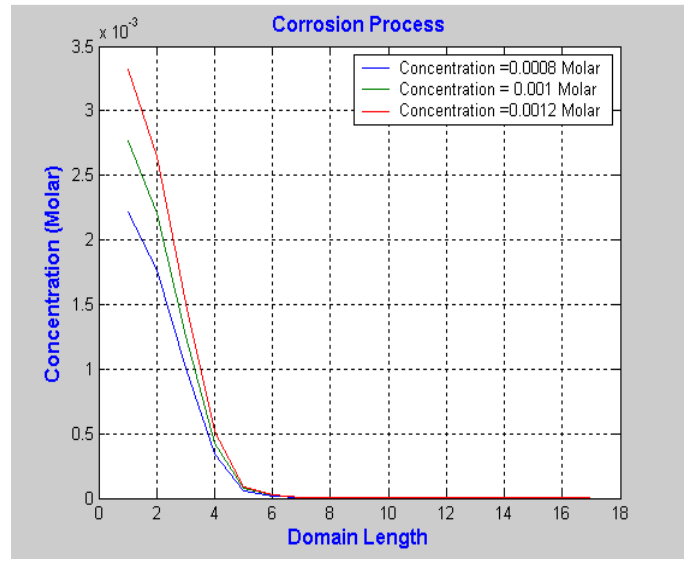

(c) 
Basuki et al.

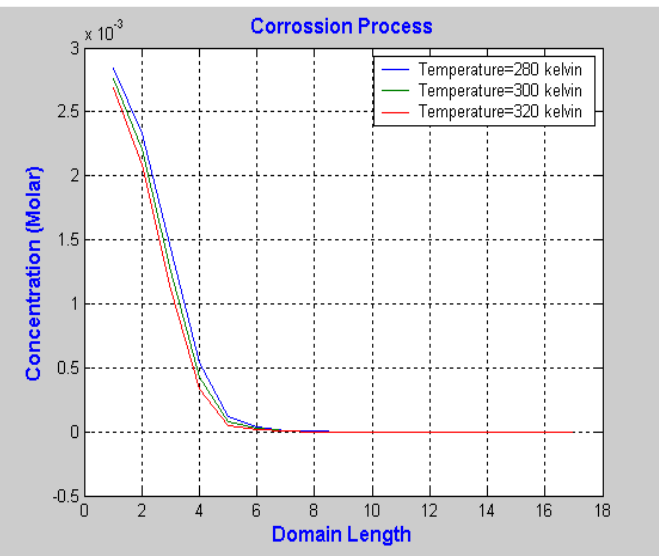

Fig. 2: Iron Corrosion Process based on difference Time (a), Concentration of Iron (b), and Temperature condensation (c).

Based on the obtained figure above, it can be determined that the relation of the longer time required. Therefore, the chances that the happening of corrosion is substantially increase, and so do on the contrary. The concentration influence of iron towards the iron corrosion process is greater than the applied iron concentration. Therefore, the possibility that the happening of iron corrosion increasingly increases and conversely. Third factor that has an effect on is condensation temperature used, ever greater of temperature used hence possibility that the happening of corrosion exactly increasingly minimizes. The statement chimes in with Planck-Nernst law about mass transport and First Faraday's law where mass that's yielded or reduced compares straight to time and concentration of metal that's applied but proportional inversely with condensation temperature.

Numerical result of the electrical potential equation is also be visualized by using MATLAB 7.0 program and it is depicted in Fig. 3:

(a)

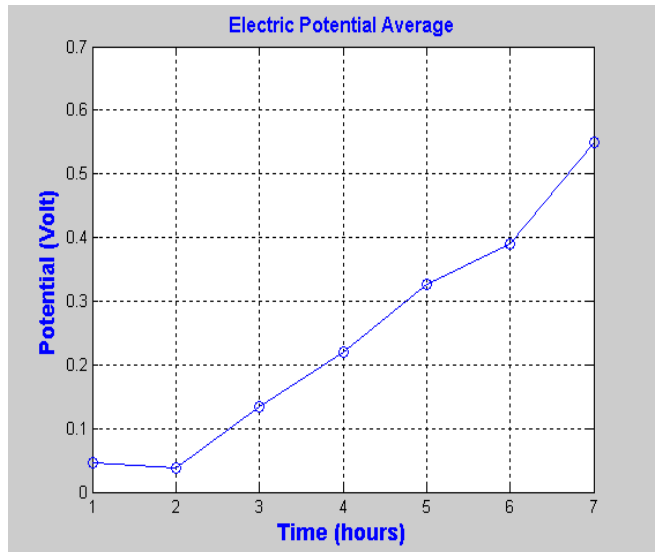

(b) 


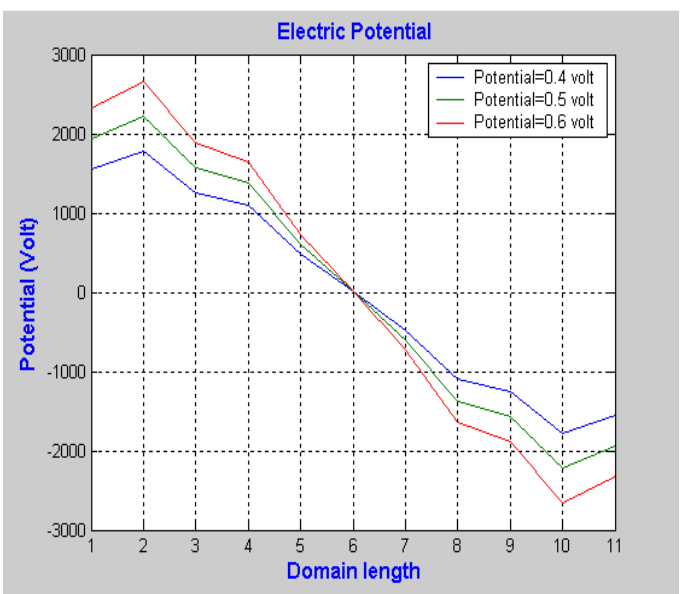

Fig. 3: Electric potential based to time difference (a) and electric potential beginning (b).

Based on the above picture, i.e. Fig. 3, which obtained for determinable electrical tension the relation of that longer time required hence level of electrical tension value of mean emerging at every node would increasingly increases, and so do on the contrary. The beginning electric potential influence that's used smaller that's applied hence electric potential average value also increasingly minimizes, and so does on the contrary. The statement chimes in with Planck-Nernst's law about mass transport, where potential electric is compared straight to time. The electrical current also arises during the corrosion process at electrochemistry cell, in which the numerical results of those equations will be visualized in the form of figures by using the MATLAB 7.0 program. The results are shown in Fig. 4:

(a)

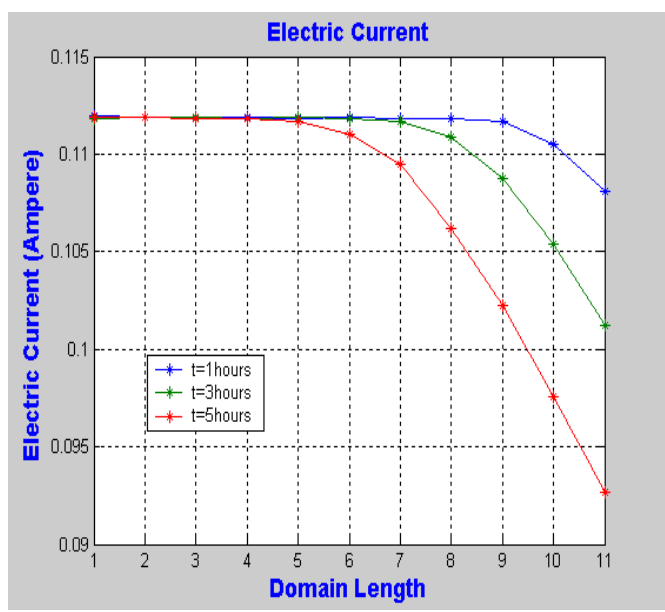

(b) 


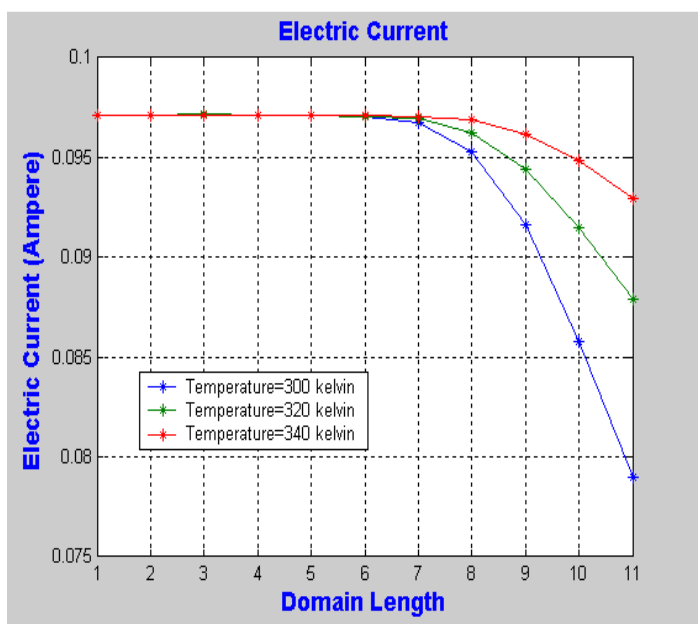

Fig. 4: Electric current based to time difference (a) and condensation temperature (b).

Based on the Fig. 4 that are obtained is known that longer time required hence electric current that emerges at every node increasingly declines, and so do on the contrary. Temperature factor also influences to electrical current value that emerges during corrosion process to take place that is ever greater of condensation temperature used hence electric current happened at every node also increasingly increased where both of those relationships chimed in with Faraday's first law and mass transport Planck-Nernst's law that is inversely proportional electric current to the time and it compares straight with the condensation temperature.

\section{CONCLUSION}

Based on the numerical simulations which have made so it can be concluded that the inferential part of gristle metal part of functioning metal as anode support, in this case there is in the beginning of metal. If the time is longer applied hence part of metal experiencing impairment concentration by the end of iteration would increasingly long in meaning of gristle area corrosion to be longer so that metal mass that reduce by the corrosion more and more and so do on the contrary. The concentration factor of initial iron also influences to corrosion process, that is value excelsior concentration of iron used hence impairment concentration of iron by the end of iteration also increasingly long in meaning of area which gristle corrosion to be broader, so that number of masses that's yielded for the concentration of larger ones has number of bigger reduced masses and so do on the contrary. Temperature factor also influences to iron corrosion that is more high condensation temperature excelsior used in condensation of electrolyte hence degradation of concentration of increasingly short, in meaning of gristle area corrosion to be more minimizes, so that mass reduced that's yielded to increasingly minimizes and so do on the contrary.

At the electrical potential increasingly of time hence the potential electrical average value also increases, while ever greater of beginning electric potential that's applied hence electric potential value which emerges at every node and electric potential average value also increases, and so do on the contrary. At electric current increasingly increasing of time hence electric current value which emerges that's increasingly minimizes, while 
IIUM Engineering Journal, Vol. 12, No. 6, 2011: Special Issue in Science and Ethics

Basuki et al.

growing of condensation temperature of electrolyte used hence electric current value which emerges to increasingly, and so do on the contrary.

\section{ACKNOWLEDGEMENT}

We would like to thank the Institut Teknologi Sepuluh Nopember-Surabaya Indonesia, which give us a grant and chance to disseminate an intellectual output of our research.

\section{REFERENCES}

[1] Shifler D. A, “Corrosion Science”, Physical Science, Vol. 47, 2005, pp. 2335-2352.

[2] Atkins P.W., Physical Chemistry, Oxford University Press, Oxford, 1990

[3] Newman, J. S., Electrochemical Systems, Prentice-Hall, Englewood Cliffs, New Jersey, 1996.

[4] Sudarmo U., Chemistry, Erlangga, Jakarta, 2006. 